Mеталлофиз. новейшие технол. / Metallofiz. Noveishie Tekhnol. (C) 2018 ИМФ (Институт металлофизики 2018, т. 40, № 9, cс. 1165-1171 / DOI: 10.15407/mfint.40.09.1165 им. Г. В. Курдюмова НАН Украины) Оттиски доступны непосредственно от издателя

Фотокопирование разрешено только

Напечатано в Украине.

в соответствии с лицензией

PACSnumbers: 06.60.Mr, 61.43.Hv, 61.72.Ff, 81.05.Bx, 81.40.Ef, 81.40.Np, 81.70.Bt

\title{
Regularization of One Conditionally Ill-Posed Problem of Extractive Metallurgy
}

\author{
V. I. Bolshakov, V. M. Volchuk, and Yu. I. Dubrov \\ Prydniprovs'ka State Academy of Civil Engineering and Architecture, \\ $24^{\underline{a}}$ Chernyshevs'ky Str., \\ 49600 Dnipro, Ukraine
}

One of the ways to solve the conditionally ill-posed problem for ranking quality criteria of the multiobjective system, whose regularization is made by applying the fractal formalism, is hereby considered. Ranking quality criteria by their importance is based on the definition of the area of self-similarity for partial criteria. At the first stage of research, the key parameter is identified under the defined initial conditions by ranking quality criteria with the use of the fractal formalism. Ranking the criteria by importance is based on the estimation of the comparative value of areas of their self-similarity. The selfsimilarity coefficients of these areas appear as the regularization parameter at this stage of research. These areas are estimated by means of definitions of their relative values as the ratio of the range for existence of each partial criterion referred to its upper boundary. The second stage of research is initiated by the need to determine the optimal combinations of the target product properties in the working area, depending on the customer conditions. For this purpose, the sub-compromise regions are defined in the working area of partial criteria under consideration (compromise criteria). The sub-compromise partial regions are regions of the optimal combinations of properties. Thus, the regularization at the second stage is made in co-ordination with the requirements of the customer. In this connection, the example of solving the conditionally ill-posed problem for optimizing the multicriteria and multiparametric technologies of fabrication of cast iron rolls is given.

Key words: multiparametric technologies, regularization parameter, selfsimilarity area, compromise criteria, mechanical properties, fractal formalism.

Corresponding author: Volodymyr Mykolayovych Volchuk

E-mail:volchuky@gmail.com

Citation: V. I. Bolshakov, V. M. Volchuk, and Yu. I. Dubrov, Regularization of One Conditionally Ill-Posed Problem of Extractive Metallurgy, Metallofiz. Noveishie Tekhnol., 40, No. 9: 1165-1171 (2018), DOI: 10.15407/mfint.40.09.1165. 
Розглядається один із шляхів вирішення умовно некоректної задачі ранжування критеріїв якости багатокритеріяльної системи, регуляризація якої проводиться застосуванням фрактального формалізму. Ранжування критеріїв якости за значенням базується на визначенні области самоподібности окремих критеріїв.

Ключові слова: багатопараметрична технологія, параметер регуляризації, область самоподібности, область компромісу критеріїв, механічні властивості, фрактальний формалізм.

Рассматривается один из путей решения условно некорректной задачи ранжирования критериев качества многокритериальной системы, регуляризация которой производится применением фрактального формализма. Ранжирование критериев качества по их значимости базируется на определении области самоподобия частных критериев.

Ключевые слова: многопараметрическая технология, параметр регуляризации, область самоподобия, область компромисса критериев, механические свойства, фрактальный формализм.

(Received March 13, 2018)

\section{PROBLEM FORMULATION}

The ranking of criteria by their importance for the multi-criteria system should ensure its stable operation within the specified limits, according to statutory documents [1]. The defined limits determine the working area of parameters. When identifying the operation of such systems, one often has to deal with complexities dictated by the influence of a number of factors that guarantee their stability. As a rule, such problems are often solved by methods of applied mathematics [2$4]$. At the same time, the majority of the applied problems of extractive metallurgy can be considered as conditionally ill-posed ones [5] that initiate the introduction of additional stipulations for their more adequate representation. Such stipulations may include the definition of the ways to optimize the multicriteria and multiparameter technologies in the working area by finding areas with the best combination of partial indicators (criteria). From this point of view, the problem of ranking quality criteria of the multiparameter technologies, examined earlier [6], taking into account the fractal formalism [7-9], seems to be incomplete and can be transformed as the conditionally ill-posed one, whose solution, depending on various initial conditions, can vary. According to J. Hadamard [10], the problem is deemed to be ill-posed, if: it has no solution (in our concerned class), it has many solutions (from two or more), and the procedure for finding the solution is unstable (i.e. with the smallest measurement error or small perturbations of the initial data [11], the solution obtained can substantially differ from the 
exact one).

Failure to fulfil, at least, one of the above-listed stipulations for the problem under consideration confirms its ill-posedness.

In spite of the fact that the first item of stipulations is fulfilled, which points to the existence of the solution for the problem of ranking quality criteria, the second and third items are not fulfilled for this problem. The second item cannot be fulfilled subject to possible changes in the customer's requirements as for the significance of partial criteria. In this regard, the ranking of criteria can be carried out according to the customer's requirements, by the degree of influence of the chemical composition elements, and by the detectable value of the area of self-similarity for each of partial criteria [6] determining the stability of the technology operation. The third item of ill-posedness stipulations cannot be fulfilled as well, since the procedure for finding one or another solution of this conditionally ill-posed problem can vary depending on periodically changing parameters in the working area (chemical composition, cooling conditions, etc.).

Proceeding from the peculiarities of the above-formulated stipulations, the solution of this conditionally ill-posed problem concerning the optimization of the multiparameter technologies is proposed to be carried out in two stages. At the first stage of the research, the key parameter is identified under the defined initial conditions by ranking quality criteria with the use of the fractal formalism. The ranking of criteria by importance is based on the estimation of the comparative value of areas of their self-similarity. The self-similarity coefficients of these areas appear as the regularization parameter at this stage of the research. These areas are estimated by means of definitions of their relative values as the ratio of the range for existence of each partial criterion referred to its upper boundary.

The second stage of research is initiated by the need to determine the optimal combinations of the target product properties in the working area, depending on the customer conditions. For this purpose, the subcompromise regions are defined in the working area of partial criteria under consideration (compromise criteria). The sub-compromise partial regions are regions of the optimal combinations of properties [12]. Thus, the regularization at the second stage is made in co-ordination with the requirements of the customer.

In this connection, the example of solving the conditionally ill-posed problem for optimizing the multicriteria and multiparameter technologies of production of cast iron rolls is given below.

\section{RESEARCH MATERIAL}

Investigated were the section-mill cast iron rolls with the globular shape of graphite, chromium and nickel alloyed. The rolls were not 
subjected to the heat treatment and had the smooth surface of barrels. The structure of the rolls in the working area (up to $\cong 50 \mathrm{~mm}$ ) had the following shape (Fig. 1).

Dimensions of the globular graphite inclusions (their diameter) on the grinding surface varied from $35 \mu \mathrm{m}$ to $59 \mu \mathrm{m}$, which corresponds to point 6 according to the standard ISO 945-75. The globular graphite in the working layer of the barrel at the depth of $\cong 5-15 \mathrm{~mm}$ is much less common to find in comparison with carbides, including ledeburite, which is explained by its content up to $\cong 3 \%$ (the standard is $\amalg \Gamma 4$ according to ГOCT 3443). The globular shape of graphite is caused by the addition of a small amount of magnesium - up to $0.054 \%$ by weight. Pearlite has the different dispersion (average distance between two adjacent cementite plates): from $0.79 \mu \mathrm{m}$ to $2.2 \mu \mathrm{m}$. The area occupied by cementite averaged $20-30 \%$ according to calculations with the use of the linear method of A. Rosival, which corresponds to the score of Ц25.

Mechanical properties of the roll-foundry iron (ultimate strength $\sigma_{B}$, ultimate bending strength $\sigma$, impact strength $K C$, Shore hardness $H S D$ ) were determined according to ГOCT 27208-87 with the use of standard techniques. The billets, from which samples were prepared for full-scale tests, have been selected from the cast samples. Samples were cut from the working area of smooth metal barrels of rolls in the tangential direction, as well as manufactured from the samples separately cast in castings. The impact strength of cast iron was determined without the notch on the samples of $10 \times 10 \times 55 \mathrm{~mm}$ size. To assess the ultimate bending strength, the samples of $10 \times 10 \times 90 \mathrm{~mm}$ were used, and in tensile tests-the samples of $25 \mathrm{~mm}$ diameter, with the gauge length of $50 \mathrm{~mm}$.

To improve the reliability of the results obtained, the data on the
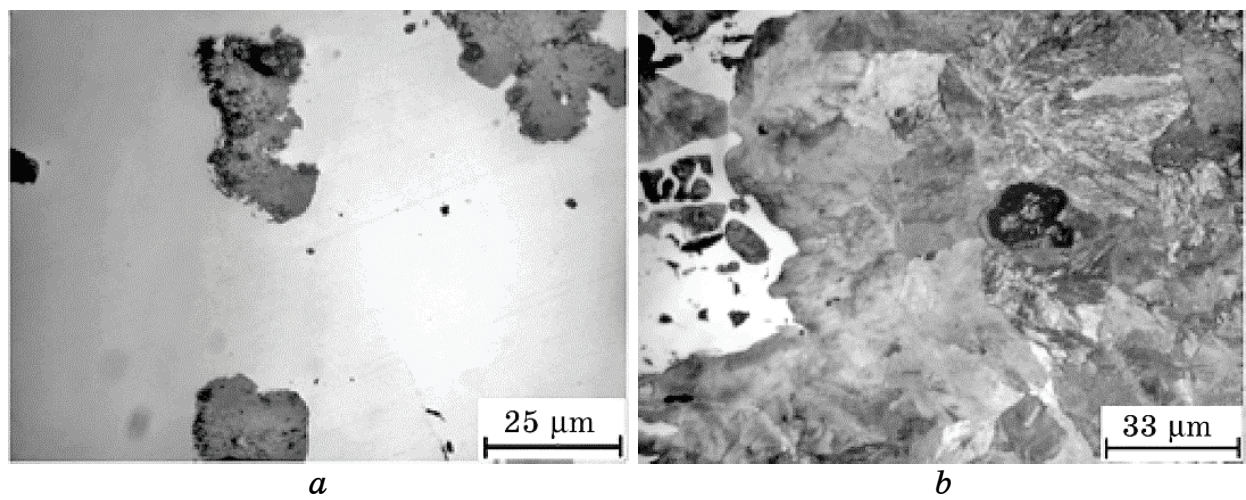

Fig. 1. Structure of the working layer of cast iron roll barrels: globular graphite $(a)$, colonies of ledeburite, graphite eutectic, pearlite matrix, $\mathrm{HNO}_{3}$ etching $(b)$. 
full-scale tests of tangential samples were used (the sampling for 283 metal fusions of the gross weight of $\cong 800$ tons) [4].

\section{EXPERIMENTAL RESULTS AND DISCUSSION}

To implement the first stage of the research, the working area of cast iron quality criteria (compromise criteria), depending on their chemical composition, is determined according to the current TУУ 14-2-1188-97 within the following limits: $\sigma_{B} \approx 240-460 \mathrm{MPa}, \sigma \approx 330-940 \mathrm{MPa}$, $K C \approx 9-33 \mathrm{~kJ} / \mathrm{m}^{2}, H S D \approx 40-60$, taking into account the whole range of applicable cooling conditions for rolls in the metal shape.

In order to determine the working area of stable indicators for quality criteria of the multiparameter technologies, their ranking by importance was carried out. The criteria ranking methodology is more particularly described in the paper [6]. The criteria ranking procedure was carried out on the basis of the analysis concerning their area of selfsimilarity. In this case, the regularization parameter for the stable operation of the technology is represented by the self-similarity coefficient.

The area of self-similarity of the normalized quality criteria for the ultimate strength varied from 240 to $460 \mathrm{MPa}$, i.e., by 220 units (within the limits of $(220 / 460) \cdot 100 \% \approx 48 \%)$. We therewith assume that the self-similarity coefficient $K_{\sigma_{B}}$ is equal to 0.48 . The self-similarity indicators for the remaining partial criteria were similarly calculated and made up for $K_{\sigma}=0.65, K_{K C}=0.73$ and $K_{H S D}=0.33$.

The key parameter among quality criteria under consideration is the impact strength having the highest self-similarity coefficient $K_{K C}=0.73$. Accordingly, indicators of the impact strength for cast iron with the structure of the globular graphite are more sensitive to changes in the in-house technology than other properties of $\sigma_{B}, \sigma$ and $H S D$ are. Since it is assumed that, for the regularization of the technology operation with respect to the key parameter $K C$, it is necessary to maintain indicators of the chemical composition and conditions for cooling of rolls within the limits prescribed by statutory documents. In case of violating the in-house technology, changes in the areas of selfsimilarity of partial criteria are possible, and consequently-changes in their ranking.

To implement the second stage of the research, the compromise criteria (Fig. 2), consisting in the normalized representation of variables, whose value is given in percentage $[12,13]$, were determined. Since this stage is aimed at finding the ways to optimize the multiparameter technologies by identifying areas with the best combination of criteria, from the point of view of the customer, the working areas of criteria represent, from these positions, their compromise criteria. Accordingly, the regularization of the technology at this stage will be to identify areas with the best combination of criteria. Regarding the key parame- 


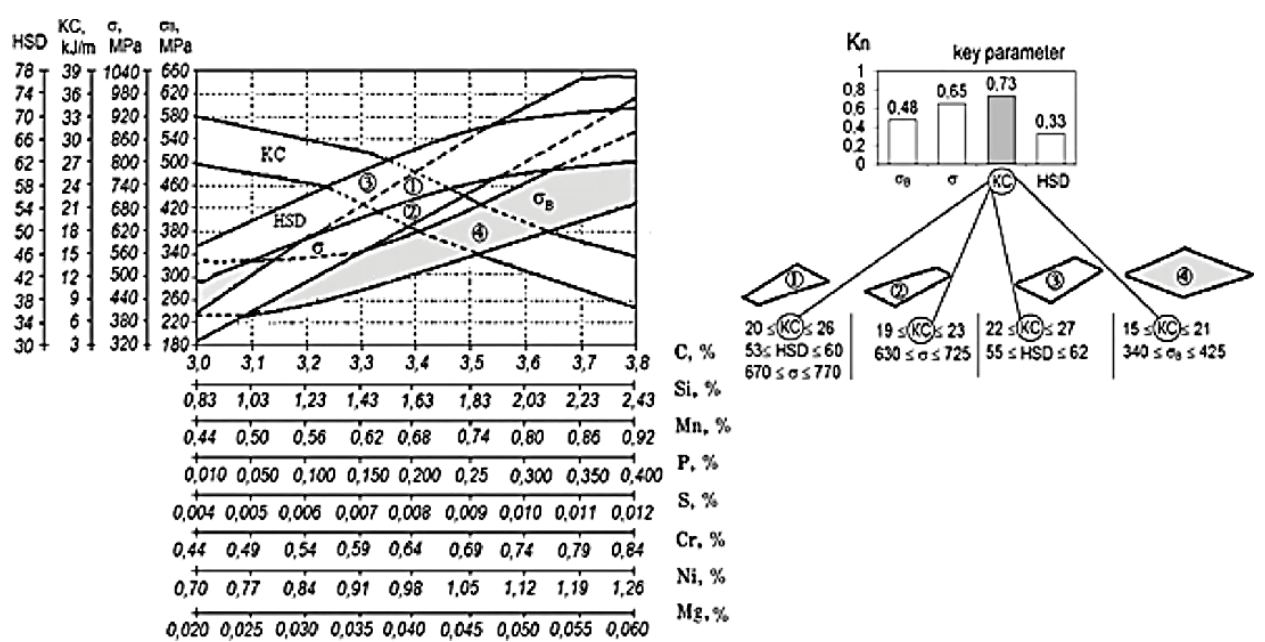

Fig. 2. The compromise criteria of the mechanical properties of cast iron as function of the chemical composition.

ter, the following segments are obtained: $1(K C-H S D-\sigma), 2(K C-\sigma), 3$ $(K C-H S D), 4\left(K C-\sigma_{B}\right)$ (Fig. 2), which makes it possible to consider these segments from the perspective of optimizing the multiparameter technologies.

Based on the customer preference, combinations of partial criteria are selected from the compromise criteria with the possibility to forecast the range of the chemical composition of the roll, which gives the opportunity for the regularization of the technology to produce cast iron rolls.

\section{CONCLUSIONS}

Therefore, the given regularization of the conditionally ill-posed problem using the fractal formalism contributes to optimization of the multiparameter technologies by choosing combinations of partial quality criteria according to the customer's preference under different initial conditions.

\section{REFERENCES}

1. Yu. Dubrov, V. Bol'shakov, and V. Volchuk, Puti Identifikatsii Periodicheskikh Mnogokriterialnykh Tekhnologiy [Paths to Identification of Periodic Multicriteria Technologies] (Saarbrucken: Palmarium Academic Publishing: 2015) (in Russian).

2. V. I. Bol'shakov, Substrukturnoe Uprochnenie Konstruktsionnykh Staley [Substructural Hardening of Structural Steels] (Toronto: Basilian Press: 1998) (in Russian). 
3. T. S. Skoblo, N. M. Vorontsov, S. I. Rudyuk, N. A. Budag'yants, and V. A. Voronina, Prokatnye Valki iz Vysokouglerodistykh Splavov [Forming Rolls from High-Carbon Alloys] (Moscow: Metallurgiya: 1994) (in Russian).

4. A. Ye. Krivosheyev, Litye Valki [Cast Rolls] (Moscow: Metallurgizdat: 1957) (in Russian).

5. A. N. Tikhonov and V. Y. Arsenin, Solutions of Ill-Posed Problems (New York: Winston: 1977).

6. V. M. Volchuk, Metallofiz. Noveishie Tekhnol., 39, No. 7: 949 (2017) (in Russian).

7. B. B. Mandelbrot, The Fractal Geometry of Nature (New York-San Francisco: Freeman: 1982).

8. O. Eh. Zasimchuk, Yu. G. Gordienko, and R. G. Gontareva, Metallofiz. Noveishie Tekhnol., 22, No. 4: 71 (2000) (in Russian).

9. V. Bolshakov, V. Volchuk, and Yu. Dubrov, Fractals and Properties of Materials (Saarbrucken: Lambert Academic Publishing: 2016).

10. J. Hadamard, Princeton University Bulletin, 13: 49 (1902) (in French).

11. S. I. Kabanikhin, Inverse and Ill-Posed Problems. Theory and Applications (De Gruyter: 2011).

12. V. I. Bol'shakov, V. M. Volchuk, and Yu. I. Dubrov, Visn. Nac. Akad. Nauk Ukr., No. 8: 66 (2013) (in Ukrainian).

13. V. I. Bol'shakov, V. N. Volchuk, and Yu. I. Dubrov, Dopov. Nac. Akad. Nauk Ukr., No. 11: 77 (2014) (in Russian). 